\title{
EDUKASI KESEHATAN DALAM MENJAMIN KETEPATAN IDENTIFIKASI PASIEN GUNA MENINGKATKAN KESELAMATAN PASIEN PADA FASILITAS PELAYANAN KESEHATAN
}

\author{
Arief Setiyoargo' ${ }^{1)}$, Nanta Sigit ${ }^{1)}$, Richard One Maxelly ${ }^{1)}$ \\ ${ }^{1)}$ Program Studi Sarjana Terapan Manajemen Informasi Kesehatan, STIKes Panti Waluya Malang, Malang, Jawa Timur, \\ Indonesia \\ Corresponding author: Arief Setiyoargo \\ E-mail : setiyoargoarief@gmail.com
}

\section{Diterima 01 Maret 2021, Direvisi 17 Maret 2021, Disetujui 17 Maret 2021}

\begin{abstract}
ABSTRAK
Kegiatan Pengabdian Masyarakat ini bertujuan untuk meningkatkan keselamatan pasien secara berkelanjutan pada fasilitas pelayanan kesehatan melalui ketepatan dalam identifikasi pasien. Kegiatan ini diawali dengan pengkajian awal terhadap keadaan lapangan saat ini pada fasilitas pelayanan kesehatan melalui tenaga kesehatan/kader kesehatan dan warga. Pengkajian awal didapati masih kurangnya edukasi mengenai identifikasi pasien, terutama di saat pandemi Covid 19 saat ini fokus pelayanan kesehatan masih terpusat pada protokoler kesehatan atau physical distancing. Hasil survei menunjukkan bahwa masih kurangnya pengetahuan tenaga kesehatan/kader kesehatan dalam menjamin ketepatan identifikasi pasien, pengetahuan terkait kejadian yang tidak diharapkan serta prosedur pelaksanaan keselamatan pasien di fasilitas kesehatan. Kegiatan dilanjutkan dengan menyusun perencanaan dan jadwal kegiatan serta perlengkapan yang diperlukan. Bentuk kegiatan dikemas dalam bentuk materi dan video tentang pentingnya menjamin ketepatan identifikasi pasien dalam pelayanan kesehatan, pemahaman tentang kejadian yang tidak diharapkan serta prosedur pelaksanaan keselamatan pasien di fasilitas pelayanan kesehatan. Kegiatan diakhiri dengan evaluasi di setiap kegiatannya. Hasil dari kegiatan pengabdian kepada masyarakat terdapat sebanyak $61,5 \%$ pemahaman warga dalam katergori baik, cukup sebanyak $23 \%$ dan kurang sebanyak $15,5 \%$. Kegiatan berjalan dengan baik dan perlu adanya monitoring lebih lanjut.
\end{abstract}

Kata kunci: identifikasi pasien; keselamatan pasien

\begin{abstract}
This Community Service activity aims to improve patient safety in a sustainable manner in health care facilities through accuracy in patient calls. This activity begins with an initial assessment of the current state of the field in health facilities through health workers and residents. Initial assessments found that there is still a lack of education regarding patient contact, especially during the Covid 19 pandemic, currently the focus of health is still focused on health service protocols or physical distance. The survey results showed that the facts of knowledge of health workers / health cadres in ensuring patient accuracy, knowledge related to unexpected events and the implementation of patient safety in health facilities. Activities by compiling a plan and schedule of activities and equipment needed. The form of activities in the material and videos about the importance of ensuring the accuracy of the patient's condition in health services, understanding of unexpected events and implementing patient safety in health care facilities. The activity ended with an evaluation of each activity. The results of community service activities were as much as $61.5 \%$ of the citizens' understanding was in a good category, $23 \%$ enough and $15.5 \%$ less. Activities are running well and further monitoring is needed.
\end{abstract}

Keywords: patient identification; patient safety

\section{PENDAHULUAN}

Pembangunan kesehatan suatu negara tidak dapat terlepas dari yang namanya sistem kesehatan nasional. Sistem kesehatan nasional sendiri dapat terlihat kualitas dan mutunya dari sejauh mana fasilitas pelayanan kesehatan dapat memberikan pelayanan yang optimal kepada masyarakat pada umum dan pasien secara khususnya. Bidang pelayanan kesehatan wajib mampu memberikan pelayanan yang baik dan tentunya menjaga keselamatan pasien.

Keselamatan pasien merupakan tantangan tersendiri bagi fasilitas pelayanan kesehatan karena butuh adanya kesadaran dan pengetahuan dari seluruh pihak yang terlibat, 
dimulai dari tenaga medis dan berlanjut pada tenaga kesehatan lainnya, serta tentunya juga dari pihak pasien dan keluarga pasien. Keselamatan pasien ini merupakan isu global yang sering dibicarakan saat ini dimana hal ini dianggap penting karena banyaknya laporan tuntutan pasien atas medical error yang terjadi pada pasien.

Berdasarkan data insiden keselamatan pasien RSUD Kota Bekasi dari bulan September 2015 sampai Maret 2016 ditemukan sebanyak 12,1\% Kejadian Tidak Diharapkan (KTD), 42,3\% Kejadian Nyaris Cedera (KNC), $41,4 \%$ Kejadian Potensial Cedera (KPC). Dari data tersebut KNC merupakan kejadian yang sering terjadi, dari $42,3 \% \mathrm{KNC}$ yang terjadi disebabkan oleh adanya kesalahan dalam mengidentifikasi pasien sebanyak $63,5 \%$ (Lunes Mutiara Cintha et al., 2016).

$$
\text { Kesalahan karena kekeliruan }
$$

identifikasi pasien terjadi di hampir semua aspek atau tahapan diagnosis dan pengobatan sehingga diperlukan adanya ketepatan identifikasi pasien. Identifikasi pasien merupakan sasaran utama keselamatan pasien yang harus dipenuhi terutamanya oleh setiap tenaga medis. Karena dengan identifikasi pasien yang benar pelayanan/pengobatan terhadap pasien dapat sesuai diberikan berdasarkan kebenaran identifikasi pasiennya.

Identifikasi pasien dilakukan pada saat sebelum melakukan tindakan keperawatan atau prosedur lain, pemberian obat, transfusi cairan atau produk darah, pengambilan darah dan pengambilan specimen lain untuk uji klinis. Cara identifikasi pasien yaitu dengan tanggal lahir, nama pasien, nomor rekam medis dan gelang berkode batang. Nomor kamar atau tempat tidur tidak dapat digunakan untuk identifikasi pasien.

Tujuan dari identifikasi pasien dengan benar ialah pertama, dengan cara yang dapat dipercaya/reliable mengidentifikasi pasien sebagai individu yang dimaksudkan untuk mendapatkan pelayanan atau pengobatan. Yang kedua, untuk mencocokkan pelayanan atau pengobatan terhadap individu tersebut.

Proses identifikasi pasien perlu dilakukan dari sejak awal pasien masuk rumah sakit yang kemudian identitas tersebut akan selalu dikonfirmasi dalam segala proses di rumah sakit. Hal ini dilakukan agar tidak terjadi keselahan identifikasi pasien yang nantinya bisa berakibat fatal jika pasien menerima prosedur medis yang tidak sesuai dengan kondisi pasien seperti salah pemberian obat, salah pengambilan darah bahkan salah tindakan medis. Penyusunan kebijkan dan atau prosedur identifikasi pasien harus dikerjakan untuk berbagai pihak agar hasilnya dipastikan dapat mengatasi semua permasalahan identifikasi yang mungkin terjadi.

Perkembangan jumlah penduduk pada suatu kawasan membawa perubahan besar pada kebutuhan dasar manusia yaitu kebutuhan akan sandang, pangan dan papan serta fasilitas penunjangnya. Kebutuhan dasar tersebut terus meningkat secara alamiah seiring kompleksitasnya kebutuhan hidup bermasyarakat seperti aktivitas sosial, aktivitas ekonomi dan aktivitas pelayanan umum. Dari kondisi tersebut menuntut adanya pembangunan sarana dan prasarana pada suatu kawasan guna menjaga kelangsungan hidup masyarakat terutamanya di daerah perkotaan. Salah satunya yaitu kebutuhan akan sarana atau fasilitas pelayanan kesehatan sebagai bentuk kebutuhan dasar manusia dalam mempertahankan keberlangsungan hidupnya. Fasilitas pelayanan kesehatan memberikan banyak manfaat diantaranya memberikan pelayanan promotif, preventif, kuratif dan rehabilitatif serta edukasi kesehatan kepada masyarakat.

Pada masa pandemi Covid 19 saat ini yang sedang melanda Indonesia dan dunia juga turut memberikan dampak di berbagai daerah di tanah air. Covid 19 bukan hanya merupakan suatu wabah biasa, melainkan sebuah pandemi sehingga WHO (World Health Organization) sebagai organisasi kesehatan dunia memberlakukan physical distancing untuk menekan penyebaran virus tersebut. Adanya kebijakan dari pemerintah utnuk memberlakukan physical distancing tersebut juga turut memberikan dampak bagi masyarakat, salah satunya yaitu pelayanan di fasilitas kesehatan. Saat ini pelayanan kesehatan hampir seluruhnya berfokus pada pengobatan dan perawatan dari pasien Covid 19 serta pemberlakuan physical distancing, tentunya hal ini sangat berpengaruh pada pemenuhan fungsi fasilitas pelayanan kesehatan dalam memberikan edukasi kesehatan. Edukasi kesehatan dirasa sangat penting terkait kegiatan pelayanan kesehatan yang diberikan sehingga dapat diwujudkan rasa saling percaya antara tenaga kesehatan dan pasien terutama mengenai jaminan keselamatan pasien pada fasilitas pelayanan kesehatan tersebut yang sangat beresiko bagi pasien itu sendiri.

Sehubungan dengan permasalahan tersebut, pihak STIKes Panti Waluya Malang melaksanakan kegiatan pengabdian kepada masyarakat dalam memberikan pembinaan, pendampingan dan konsultasi dalam pentingnya menjamin ketepatan identifikasi pasien dengan pembinaan terkait pemahaman keselamatan pasien serta prosedur 
pelaksanaan identifikasi pasien yang benar dan tepat sehingga dapat digunakan untuk meningkatkan pelayanan kesehatan masyarakat terutama mengenai keselamatan pasien secara berkelanjutan pada fasilitas pelayanan kesehatan.

\section{METODE}

Pelaksanaan kegiatan pengabdian masyarakat ini berlangsung selama 3 kali pertemuan kepada warga RT.4 RW.4 Kel. Jati Kec. Mayangan Kota Probolinggo yang berjumlah sebanyak 26 orang. Karakteristik warga diantaranya merupakan bapak-bapak dan ibu-ibu yang aktif pada berbagai kegiatan kesehatan dan kemasyarakatan. Adapun warga yang memiliki pekerjaan sebagai tenaga kesehatan sebanyak 2 orang. Metode pelaksanaan yang diterapkan untuk mencapai tujuan dari program kemitraan ini adalah dimulai dari tahap persiapan, tahap pelaksanaan dan tahap evaluasi.

Tahap persiapan dilakukan dengan mengurus birokrasi dan permohonan ijin kepada pihak terkait, pertemuan dengan tokoh masyarakat dan petugas kesehatan, mengobservasi prosedur pelayanan kesehatan antara tenaga kesehatan dan pasien.

Tahap pelaksanaan dilakukan dengan memberikan sosialisasi bagi tenaga/kader kesehatan dan masyarakat secara daring mengingat dalam kondisi pandemi Covid 19, mengenai pentingnya menjamin ketepatan identifikasi pasien dalam pelayanan kesehatan, pemahaman tentang kejadian yang tidak diharapkan serta prosedur pelaksanaan keselamatan pasien di fasilitas pelayanan kesehatan.

Tahap evaluasi dilakukan untuk menilai tingkat pemahaman kader terkait pentingnya menjamin ketepatan identifikasi pasien dalam pelayanan kesehatan, pemahaman tentang kejadian yang tidak diharapkan dalam prosedur pelaksanaan keselamatan pasien pada fasilitas pelayanan kesehatan. Evaluasi dilakukan melalui tanya jawab langsung pada awal penyuluhan dan post test dilakukan pada akhir tahap penyuluhan.

\section{HASIL DAN PEMBAHASAN}

HASIL

Tabel 1. Distribusi Frekuensi peserta PKM Berdasarkan Jenis Kelamin

\begin{tabular}{cccc}
\hline No. & $\begin{array}{c}\text { Jenis } \\
\text { Kelamin }\end{array}$ & Frek. & Prosentase \\
\hline 1. & Laki-laki & 13 & $50 \%$ \\
2. & Perempuan & 13 & $50 \%$ \\
\hline
\end{tabular}

$$
\text { Total }
$$$$
26
$$$$
100 \%
$$

Distribusi Peserta berdasarkan profesi dapat dilihat pada tabel 2 berikut:

Tabel 2. Distribusi Frekuensi peserta PKM Berdasarkan Profesi

\begin{tabular}{cccc}
\hline No. & Profesi & Frek & Prosentase \\
\hline 1. & $\begin{array}{c}\text { Tenaga } \\
\text { Kesehatan }\end{array}$ & 2 & $7,7 \%$ \\
2. & Pedagang & 11 & $42,4 \%$ \\
3 & $\begin{array}{c}\text { Pekerja } \\
\text { Kantor } \\
\text { Ibu } \\
\text { Rumah } \\
\text { Tangga }\end{array}$ & 6 & $23 \%$ \\
4. & 7 & 26,9 \\
\hline & Total & 26 & $100 \%$ \\
\hline
\end{tabular}

Hasil kegiatan pada tanggal 16 Januari 2021 terkait penyampaian materi tentang pentingnya menjaga keselamatan pasien dengan metode ceramah dan tanya jawab berhasil dilaksanakan dengan indikator peserta mampu memahami materi yang disampaikan secara umum. Selanjutnya, hasil kegiatan pada tanggal 23 dan 30 Januari 2021 terkait pemahaman insiden pada fasilitas pelayanan kesehatan serta prosedur pelaksanaan keselamatan dan identifikasi pasien melalui metode pemberian materi dan video pembelajaran serta tanya jawab secara online melalui grup whatsapp juga berhasil dilaksanakan dengan indikator peserta mampu mengerti materi tentang prosedur pelaksanaan identifikasi pasien yang benar.

Hasil tanya jawab online melalui grup whatsapp dapat dilihat pada gambar berikut:

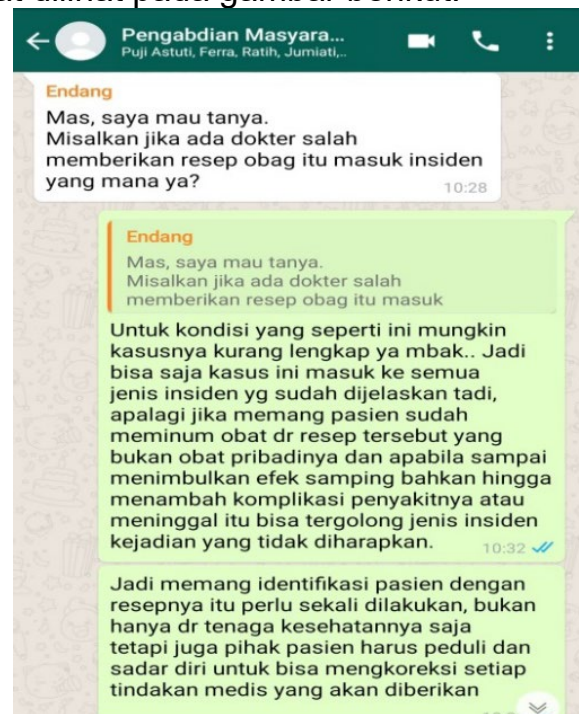

Gambar 1. Tanya jawab tentang Jenis Insiden Keselamatan Pasien 


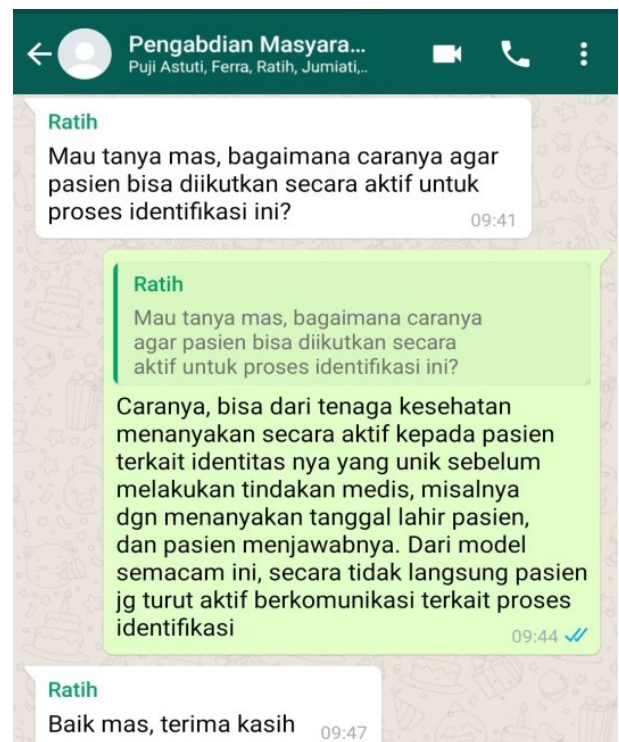

Gambar 2. Tanya Jawab tentang Prosedur Identifikasi Pasien

Distribusi Peserta berdasarkan pemahaman materi dapat dilihat pada tabel 3 berikut:

Tabel 3. Distribusi Frekuensi peserta PKM Berdasarkan Pemahaman materi

\begin{tabular}{cccc}
\hline No. & Pemahaman & Frek & Prosentase \\
\hline 1. & Baik & 16 & $61,5 \%$ \\
2. & Cukup & 6 & $23 \%$ \\
3 & Kurang & 4 & $15,5 \%$ \\
\hline & Total & 26 & $100 \%$ \\
\hline
\end{tabular}

\section{PEMBAHASAN}

Pada gambar 1 , terdapat pertanyaan dari peserta yang mewakili warga setempat yang bertanya terkait jenis insiden yang terjadi ketika ada salah seorang dokter salah dalam memberikan resep obat kepada salah satu pasiennya. Dari pertanyaan peserta tersebut, dijawab oleh pemateri bahwa kesalahan identifikasi yang menyebabkan efek samping bagi pasien, menambah komplikasi penyakit hingga meninggal itu tergolong dalam kategori insiden kejadian yang tidak diharapkan, hal ini sudah sesuai dengan yang tercantum pada (World Health Organization, 2015).

Kejadian Tidak Diharapkan (KTD) / Adverse Event adalah suatu kejadian yang mengakibatkan cedera yang tidak diharapkan pada pasien karena suatu tindakan ("commission") atau karena tidak bertindak ("omission"), bukan karena "underlying disease" atau kondisi pasien (Tutiany et al., 2017). Dampak yang ditimbulkan dari KTD dapat merugikan baik pihak rumah sakit, staf yang terlibat terutama pasien yang menerima layanan (Ristekdikti, 2015). Dampak yang ditimbulkan antara lain menurunnya tingkat kepercayaan masyarakat terhadap pelayanan kesehatan, rendahnya kualitas atau mutu asuhan yang diberikan, karena keselamatan pasien adalah bagian dari mutu dan tentunya tuntutan hukum terkait cedera yang dialami pasien karena rumah sakit wajib mendahulukan keselamatan nyawa pasien (DPR RI, 2009). Kondisi ini harus mampu diantisipasi oleh penyelenggara layanan agar keselamatan pasien terjamin, kontinuitas pelayanan dan organisasi tetap berjalan.

Pada gambar 2, terdapat pertanyaan dari peserta yang mewakili tenaga kesehatan setempat terkait prosedur identifikasi yang melibatkan pasien secara aktif. Dari pertanyaan peserta tersebut dijawab oleh pemateri bahwa identifikasi pasien bisa dilakukan secara aktif kepada pasien, dengan cara pasien menjawab pertanyaan yang diajukan oleh tenaga kesehatan seperti halnya tanggal lahir pasien dan nama orang tua, sehingga pasien ikut berperan aktif dalam komunikasi antara pasien dengan tenaga kesehatan. Hal ini sejalan dengan penelitian yang dilakukan oleh (Lunes Mutiara Cintha et al., 2016) bahwa pasien juga dapat ikut berpatisipasi aktif dalam proses komunikasi terkait prosedur identifikasi pasien tersebut.

Pelaksanaan identifikasi dilakukan selama proses pelayanan. Verifikasi yang dilakukan kepada pasien terkait proses identifikasi merupakan kegiatan rutin yang harus dilakukan selama kegiatan pelayanan berlangsung (The Joint Commission, 2011). Untuk itu diperlukan pendekatan untuk membudayakan nilai-nilai safety ini kepada seluruh tenaga kesehatan dan juga pasien. Dalam hal ini, kerjasama dengan pasien dan keluarga maupun orang terdekat sangatlah diperlukan, karena pasien perilu diberikan penjelasan yang cukup tentang tujuan dari proses identifikasi ini dan resikonya jika tidak dilakukan (Anggraini et al., 2014).

$$
\text { Kegiatan pengabdian kepada }
$$

masyarakat mengenai upaya menjaga ketepatan identifikasi pasien di RT.4 RW.4 Kel. Jati Kec. Mayangan Kota Probolinggo secara daring ini telah berhasil dilaksanakan. Hasil evaluasi setelah dilaksanakannnya kegiatan pengabdian kepada masyarakat ini didapati masih adanya warga yang belum memahami pentingnya menjaga ketepatan identifikasi pasien tersebut sebanyak $15,5 \%$. Hal ini sangat wajar karena materi yang disampaikan adalah pengetahuan yang baru dan diperlukan ketekunan dalam memahami ketepatan identifikasi pasien tersebut. Namun, dalam 
implementasi upaya menjaga ketepatan identifikasi pasien ini perlu adanya kepedulian dan perhatian dari para tenaga/kader kesehatan serta warga masyarakat sebagai pasien dalam hal pemahaman terkait keselamatan pasien sehingga dapat terciptanya rasa saling percaya terkait tugas dan fungsi masing-masing.

Oleh karena itu, perlu suatu inisiatif atau kesadaran dari para tenaga/kader kesehatan untuk bisa berkomunikasi aktif kepada pasien sehingga pasien dapat memahami bentuk sebuah prosedur identifikasi pasien yang penting dalam sebuah pelayanan medis sehingga tercapai derajat pelayanan fasilitas kesehatan yang baik dan berkualitas terutamnya dalam hal keselamatan pasien.

\section{SIMPULAN DAN SARAN}

Pengabdian kepada masyarakat dengan judul "Edukasi Kesehatan Dalam Upaya Menjamin Ketepatan Identifikasi Pasien Guna Meningkatkan Keselamatan Pasien Pada Fasilitas Pelayanan Kesehatan" yang dilakukan di RT.4 RW.4 Kel. Jati Kec. Mayangan Kota Probolinggo telah selesai dilaksanakan secara daring dengan pemberian materi secara online melalui grup whatsapp, tanya jawab virtual dan akses video pembelajaran. Hasil dari kegiatan yaitu peserta diantaranya tenaga/kader kesehatan dan warga masyarakat sudah mampu untuk mengerti mengenai pentingnya menjamin ketepatan identifikasi pasien dalam pelayanan kesehatan, pemahaman tentang kejadian yang tidak diharapkan serta prosedur pelaksanaan keselamatan pasien di fasilitas pelayanan kesehatan.

\section{UCAPAN TERIMAKASIH}

Pengabdi mengucapkan terima kasih kepada warga dan Ketua RT.4 RW.4 Kel. Jati Kec. Mayangan Kota Probolinggo yang bersedia menjadi subjek binaan dalam pengabdian kepada masyarakat ini. Tidak lupa pula pengabdi mengucapkan terima kasih kepada Lembaga Penelitian dan Pengabdian Kepada Masyarakat STIKes Panti Waluya Malang yang membiayai pengabdian kepada masyarakat ini.

\section{DAFTAR RUJUKAN}

Anggraini, D., Hakim, L., \& Widjiati Imam, C. (2014). Evaluasi Pelaksanaan Sistem Identifikasi Pasien di Instalasi Rawat Inap Rumah Sakit. Jurnal Kedokteran Brawijaya, 28(1), 99-105. https://doi.org/10.21776/ub.jkb.2014.0 28.01.32

DPR RI. (2009). Undang-Undang Dasar Negara Republik Indonesia No. 36 tahun 2009 tentang Kesehatan.

KEMENKES. (2017). Peraturan Menteri Kesehatan Republik Indonesia Nomor 11 Tahun 2017 Tentang Keselamatan Pasien Dengan. In Progress in Physical Geography (Vol. 14, Issue 7, p. 450). https://tel.archives-ouvertes.fr/tel01514176

Lunes Mutiara Cintha, G., Suryoputro, A., Patria Jati BagianAdministrasi dan Kebijakan Kesehatan, S., \& Kesehatan Masyarakat, F. (2016). Fitri. 4, 23563346.

Ristekdikti, K. (2015). Modul Pelatihan Keselamatan Pasien.

The Joint Commission. (2011). Patient identification policy. Patient Safety Solutions, 1(May), 1-26.

Tutiany, Lindawati, \& Krisanti, P. (2017). Bahan Ajar Keperawatan: Manajemen Keselamatan Pasien. Pusat Pendidikan Sumber Daya Manusia Kesehatan Kementerian Kesehatan RI, 297.

World Health Organization. (2015). Panduan Kurikulum Keselamatan Pasien. 272. 